\title{
Geographies of Temporary Markets: An Anatomy of the Canton Fair
}

\author{
Harald Bathelt, Pengfei Li \& Yi-wen Zhu
}

\author{
Version Post-print/accepted manuscript \\ Citation Bathelt, H., Li, P., \& Zhu, Y. W. (2017). Geographies of temporary \\ (published version) markets: an anatomy of the Canton Fair. European Planning Studies, 25(9), \\ 1497-1515.
}

\section{Copyright / License}

Publisher's Statement

This is an Accepted Manuscript of an article published by Taylor \& Francis in European Planning Studies on May 2017, available online: https://www.tandfonline.com/doi/abs/10.1080/09654313.2017.1327034

How to cite TSpace items 


\title{
Geographies of Temporary Markets: An Anatomy of the Canton Fair
}

\author{
Harald Bathelt \\ University of Toronto, Department of Political Science \\ and Department of Geography and Planning, \\ Sidney Smith Hall, 100 St. George Street, Toronto, ON M5S 3G3, Canada; \\ E-mail: harald.bathelt@utoronto.ca, URL: http://www.harald-bathelt.com

\section{Pengfei Li} \\ HEC Montréal, Department of International Business, \\ 3000, chemin de la Côte-Sainte-Catherine, Montréal, QC H3T 2A7, Canada; \\ E-mail: li.pengfei@hec.ca

\section{Yi-wen Zhu} \\ East China Normal University, School of Urban and Regional Science, \\ 3663 North Zhongshan Road, Shanghai 200062, PR China; \\ E-Mail: zhuyiwen19@163.com
}

Paper resubmitted to

European Planning Studies 


\title{
Geographies of Temporary Markets: An Anatomy of the Canton Fair
}

\begin{abstract}
While recent research on temporary clusters and temporary markets has emphasized the knowledge generation processes associated with trade fairs, little is known about the knowledge exchanges that are embedded in market relations at these events. This paper uses the case of the Canton Fair in Guangzhou, the largest trade fair in China, to illustrate that such events do not operate as a single market but that they generate multiple dynamic market configurations, which entail different flows of knowledge, goods and people. In a typical case study, four types of market configurations are identified that simultaneously develop at this event. The findings contribute to a more comprehensive understanding of the dynamics of market relations, knowledge and transactions in temporary spatial settings.
\end{abstract}

Keywords: Canton Fair; dynamic market relations; geographies of markets; multiple market configurations; knowledge flows; temporary markets

\section{Introduction}

In the past decade, academic studies have made substantial progress in understanding the nature and patterns of knowledge flows in temporary spatial settings, such as trade fairs (Borghini et al. 2006; Skov 2006; Evers and Knight 2008; Power and Jansson 2008; Bathelt and Schuldt 2010; Ramírez-Pasillas 2010; Rinallo and Golfetto 2011; Moeran and Pedersen 2011; Kalafsky and Gress 2013; Li 2014). Trade fairs as 'temporary markets' not only provide an opportunity for exhibitors and buyers to conduct business but also enable them to interact and share product and market information. In flagship events, knowledge exchanges occur not only vertically but also horizontally as firms are able to observe their competitors' offerings and catch up with market dynamics. In such contexts, trade fairs act in a broad sense as 'temporary clusters' for learning and knowledge generation. Debates about 'temporary clusters' and 'temporary markets' have emphasized the role these events play in the globalizing knowledge economy (Maskell et al. 2006; Bathelt et al. 2014). While moving beyond traditional transactional understandings of trade fairs, such conceptualizations have paid little attention to examining the nature of traded activities at these events and how knowledge exchanges are 
embedded in market relations. Although recent studies have shown interest in the role of marketmaking in temporary contexts (e.g. Aspers and Darr 2011; Glückler and Panitz 2015; Haisch and Menzel 2015), little is known about the processes of how market relations unfold during a trade fair and how these relations impact flows of knowledge, goods and people in the real economy.

To address this shortcoming, this paper investigates how market relations are established at the Canton Fair (or China Import and Export Fair) in Guangzhou, the largest trade fair in China, and how they configure different patterns of knowledge flows and production relations. This fair is particularly well suited as a case for this research since it was originally designed to facilitate market exchanges between Chinese producers and worldwide buyers (Jin and Weber 2008; Bathelt and Zeng 2015). Due to its fast growth, the event changed its exhibition halls four times and moved into a new expanded exhibition center in 2008, i.e. the China Import and Export Fair Complex, which was specifically built to host this fair twice a year. In spring 2015, the event attracted about 185,000 visitors, mostly representatives of international buyers, and 25,000 exhibitors, mostly Chinese producers and traders (Table 1).

$* * * * * * * * * * * * * * * * * * * * * * * * * * * * * * * * * * * *$

Insert Table 1 about here

$* * * * * * * * * * * * * * * * * * * * * * * * * * * * * * * * * * * *$

Its organizer has consistently positioned the Canton Fair as a catalyst for international trade in bringing together Chinese producers/sellers with international buyers, despite substantial changes in the nature of both the Chinese economy and the event itself. Although the Canton Fair has become an advanced learning space for exhibitors and visitors alike (Li and Bathelt 2017), it is still focused on foreign trade and transaction relations today (Luan 2015). By investigating this evolving event, this paper aims to show, first, that the Canton Fair generates a 
temporary context that produces multiple market configurations rather than a single export channel and, second, that these relationships are continuously transformed and become more embedded over time. This indeed leads to the development of complex market geographies of such temporary gatherings. With these findings, we contribute to the burgeoning literature of how markets are made, particularly linking to the work of Callon $(1998 ; 2017)$. While there is a now rich literature that studies the performativity of markets (i.e. Callon 1998; 2007; Thrift 2000; MacKenzie and Millo 2003; MacKenzie et al. 2007; Berndt and Boeckler 2009), little is known about co-existing market configurations, their specific framings and dynamics over time, especially in temporary settings.

This study is organized as follows. Section 2 presents the conceptual basis of the paper. Here, we argue that trade fairs generate a context that allows exhibitors and visitors to search for and select transaction partners and simultaneously develop different forms of embedded market relations that deviate from anonymous market exchanges in the neoclassical understanding. After discussing our research approach in section 3, section 4 documents four types of market configurations identified at the Canton Fair and outlines the associated flows of knowledge, people and goods. Finally, section 5 summarizes and concludes.

\section{Trade Fairs as Dynamic Mixtures of Market Configurations}

Recent research on trade fairs has used a knowledge-based perspective to conceptualize these events as places that generate temporary proximity between the individual and collective actors in an industry or organizational field and allow these actors to exchange, transfer and circulate knowledge about new and existing products, processes and market opportunities (Bathelt et al. 2014). As expressed in the concept of the temporary cluster (Maskell et al. 2006), these events are characterized by intense sequences of interactions and observations between 
exhibitors and different groups of visitors that generate complex knowledge ecologies (Bathelt and Schuldt 2010). Associated learning processes help firms understand market trends, maintain or build customer relationships, access new technological developments and find new partners in research, production and marketing. While many trade fairs are characterized by a growing share of 'atypical' visitors that have no intention of buying (Borghini et al. 2006), even these events still focus market interactions between producer-sellers and visitor-buyers/users (Golfetto 2004; Power and Jansen 2008; Ramírez-Pasillas 2008).

Rinallo and Golfetto (2011) have introduced the concept of the temporary market to analyze market-related interaction between exhibitors and visitors. They emphasize that these interrelationships involve crucial knowledge flows that differ with the nature of the event. In a basic categorization, they distinguish four primary types of trade fairs, according to the proportion of domestic and international exhibitors and visitors: local exchange fairs, export fairs, import fairs and global exchange or hub events (Golfetto 2004). Export-oriented trade fairs like the Canton Fair bring together predominantly national exhibitors with international visitors (Rinallo and Golfetto 2011). They develop in regions with highly-developed specialized manufacturing activities, such as the production clusters in the Third Italy (Bathelt et al. 2014), or - as in China - in dynamic developing economies with a fast-growing manufacturing sector that targets foreign markets to trigger further development. The technological learning potential in the early stages of these events may be limited as horizontal interaction primarily involves exhibitors from the same national context that do not yet have the capability to develop sophisticated technologies (Li 2014); over time, however, intensive interaction and exchanges with visitors may help producers better understand the needs of buyers through participation in 
consecutive such events (Norcliffe and Rendace 2003; Power and Jansen 2008). Based on these experiences they learn how to invest in new technologies and innovate in their markets.

The above considerations clearly illustrate two points. First, the structure of knowledge flows at trade fairs is not constant but undergoes changes over time due to the periodic character of these events and associated learning processes of the participants. Second, the concepts of temporary markets and temporary clusters emphasize the knowledge flows that structure these events or derive from them, while the specific market relationships that support knowledge exchanges remain widely unexplored.

It should be clear from the outset that the form of market relationships that unfold at a trade fair are different from the price-based adjustment processes described in the neoclassical market model. Actor-network theory, especially the work of Callon (1998) on how markets are established, clearly shows that neoclassical market constellations are by no means natural and can only form under specific circumstances (Entwistle 2009; Berndt and Boeckler 2009). Even at a very large event, such as the Canton Fair, the participating buyers and sellers are not anonymous or atomistic as assumed in the neoclassical market model. In fact, both try to escape the context of anonymity and actively look for specific transaction partners to deal with (Sharland and Balogh 1996). In other words, they aim to transform the anonymous market context into one-on-one relational situations where one exhibitor negotiates with one visitor (Callon 2017).

A transaction under such circumstances is not a standardized economic process. Negotiations and intensive exchanges take place through which the market relation becomes contextualized. In Callon's (1998) terminology, framing takes place. For instance, if buyers have specific requirements, then complex market arrangements are initiated through the interaction 
between producers and users. This sometimes goes beyond the immediate transaction relation and may involve product improvements and even joint innovation activities. Such interaction processes and market relations depend on the particular technology and firm context and extend over a longer period. A good illustration of this is provided by Entwistle (2009) in her analysis of the construction of fashion markets, in which culture and esthetics enter the framing process (see, also, Skov 2006).

In multilateral market situations at trade fairs with many competing sellers and buyers, both groups of actors try to gain the attention of each other and provide information that enables them to narrow down their choices and engage in one-on-one negotiations (Callon 2017). Exhibitors, for instance, develop innovation strategies to differentiate themselves from their competitors and gain the attention of specific buyers and, through this, actively try to constitute markets (Loasby 2000). They use product variation as a way to eliminate direct competition and move from a multilateral non-personal market situation into a bilateral negotiation context, in which they start discussions with a specific customer interested in their distinct offerings. Actors develop social relations with the goal to conclude a particular contract (Aspers and Darr 2011) and product variation and innovation become strategies to escape competition (Callon 2017).

Since innovation is a successful mechanism to establish one-on-one negotiation situations, constant changes in products and exhibits become a norm and trigger intrinsic market dynamics across the sequence of such events. To reduce the uncertainties of complex multilateral markets, firms are required to innovate in order to gain specific buyer interest at the trade fair. At the same time, they greatly benefit for the multilateral market environment because it enables them to find those partners that fit their competencies well. The trade fair as a market context is configured in such a way that anonymous transactions are eliminated in favor of bilateral exchange processes. 
As the conclusion of negotiations may be delayed until further discussions after the event, more durable exchange relationships and longer-term producer-user interaction often develop (Rosson and Seringhaus 1995). Hence the trade fair does not generate the conditions for neoclassical exchange relations - it eliminates them (Callon 2017) - and firms become more competitive the more they are able to engage in bilateral negotiations.

There are several consequences that derive from these market relations. First, the tendency to move from multilateral to bilateral market relationships drives innovation and differentiation activities and creates complex market dynamics, such that the type of market relationships at the trade fair is subject to constant change over time. Second, we cannot expect one specific form of market relationship but need to realize that multiple types develop depending on the specific products, technologies and actors' needs in a given situation.

This is a process described by Callon (1998) as one of framing or contextualizing transactions. It involves what he calls the disentanglement of the product from its former use and former owner. It is through this process that the actors involved in a negotiation are able to calculate, as Callon (1998) puts it, and reach a conclusion in their negotiation. The process of disentanglement involves, for instance, discussions about the delivery details and negotiations about price. In the process, it is important for the buyer to be able to draw connections with the specific conditions under which the product has been produced and to learn about the characteristics of the product and the competencies of the producer. Conversely, the seller wants to know about the future entanglement of the product and needs information about the buyer's use context to present an appropriate package or solution to that user. It is this type of framing that necessarily generates an embedded relationship (Granovetter 1985) and reduces uncertainties as the buyer becomes aware of the producer and the production context (former 
entanglement) and the seller about the future user's specific needs. "No calculation is possible without this framing which allows one to provide a clear list of entities, states of the world, possible actions and expected outcomes of these actions" (Callon 1998: 19).

One side effect of this contextualization process at the trade fair is that it produces knowledge spillovers, which generate enormous learning opportunities for the participants in these bilateral negotiations. Of course, not all interactions between exhibitors and visitors at a fair lead to sales activities. Sometimes the parties cannot find a common ground for a contract conclusion or find that their specific competencies do not fit. At other times, negotiations may be preliminary and a visitor may move on and eventually find another exhibitor that provides a better or more fitting solution. During an event, many interactions are of this latter type and do not lead to contract conclusions. These interactions establish a rich and unique knowledge ecology or 'global buzz' that makes these events so valuable (Gibson and Bathelt 2014). As Callon (1998: 38) puts it, "[a]ny framing produces overflowing, and any procedure of disentanglement produces new attachments". In other words, it is the very nature of the 'global buzz' at trade fairs that generates manifold knowledge spillovers and triggers dynamic learning processes (Bathelt and Schuldt 2010).

Based on these considerations, three propositions are made in this paper. First, we propose that a trade event, such as the Canton Fair, does not establish a single homogenous market for transactions between sellers and buyers but generates multiple forms of market relationships, which exist simultaneously (proposition 1). Second, the nature of these events suggests that market relationships necessarily change over time. We thus expect to find multiple temporary stabilizations of market configurations at a trade fair (proposition 2). Third, since these configurations are contextual in nature and depend on the respective organizational field, 
we propose that they involve different kinds of interaction, extend over different time periods and generate different flows of knowledge, people and artifacts over space (proposition 3). The central agenda of this research is therefore to illustrate that trade fairs generate multiple dynamic market configurations that produce different market geographies.

\section{Methodology}

In our research, we adopted a typical case study approach to explore the nature and dynamics of market relations at trade fairs (Seawright and Gerring 2008; Tokatli 2015). The Canton Fair provides an excellent example to explore such market configurations due to its large size, long history and focus on sales relations ( $\mathrm{Li}$ and Bathelt 2017). It was established as a periodic marketplace in 1957 to connect Chinese exhibitors with international buyers when China was isolated from the world market (Jin and Weber 2008). Since the beginning, it was characterized by strong government support and involvement. This is even true today, as the Canton Fair is hosted by the Chinese Ministry of Commerce and the Government of Guangdong Province and organized by the China Foreign Trade Centre. The fair can be classified as a modern trade event that clearly meets international standards (Bathelt and Zeng 2015).

The Canton Fair is organized as a multi-industry export-oriented event where Chinese producers and traders offer their products to international visitors. It lasts much longer than an average trade fair (Bathelt et al. 2014), stretching over three weeks, split up according to different industry groups. Our empirical investigations focused on the third week of 117 th session of the Canton Fair in spring 2015 (China Import and Export Fair 2015). While the first phase (April 15-19) hosted electronics, machinery, vehicles, building materials, lighting equipment and chemical and energy-related products, the second phase (April 23-27) focused on consumer goods, gifts and home decors. In the third phase (May 1-5), which we attended, the 
event exhibited products surrounding textiles and garments, shoes, cases and bags, office supplies, medical devices and health and food products. Given the variety of exhibits in the third phase, we believe that the main findings regarding our propositions also apply to other stages of the event and not just to a specific set of industry groups.

Of the 25,000 exhibitors at the fair, the provinces of Guangdong and Zhejiang each accounted for over 20 percent of the exhibitors while another 10 percent originated from Fujian and Jiangsu, respectively (Dai et al. 2012). Exhibitors do not register directly with the organizer but are required to apply through their home provincial government. As a result, a pre-selection of exhibitors takes place at the provincial level. Although the pre-selection standards may vary across provinces, this process generates a more reliable and experienced set of exhibitors overall and reduces the risk of opportunism at the event. Conversely, visitors directly register with the organizer and have to identify their business when doing so. Overall, the process of exhibitor and visitor selection serves to increase the credibility of participating firms and strengthen the event's reputation (e.g. Glückler and Armbrüster 2003) as a marketplace for transactions at a relatively low risk.

Following standard procedures of qualitative research (Miles and Huberman 1994; Yin 2009), we conducted semi-structured interviews in 'close dialogue' (Clark 1998) with exhibitors to examine the nature of market relations at the Canton Fair. Interviewees were selected randomly in the exhibition halls across industry groups. In addition, we conducted systematic participatory observations of the interaction processes between exhibitors and visitors. Most interviews were recorded and transcribed. Observations were summarized and typed up during the fieldwork. Later, the transcripts were systematically analyzed according to interaction 
characteristics in market relations. Results were triangulated to substantiate the typology of market configurations developed.

Each interview was structured into two parts. The first part consisted of open-ended questions regarding the participation and learning processes of exhibitors. The second part focused on the nature of customer and competitor interaction and the flows of knowledge, people and products generated by the event. Respondents were first prompted to provide some basic information and explain why they participated in the event. After these general questions, each interviewee was asked how networks were generated, deals made, trust with buyers developed and horizontal learning accomplished. Further questions focused on the specific nature of interaction processes with customers/buyers and competitors in terms of the contents discussed, the role of innovation processes and the social relations with other firms. In the end, 55 interviews were conducted with randomly selected exhibitors, with a high response rate of about 80 percent.

\section{Multiple Market Geographies at the Canton Fair}

Almost all Chinese exhibitors in our sample were exporters whose business was largely focused on overseas markets. As hypothesized in our conceptual debate, we did not encounter any market configuration at the Canton Fair that was similar to the neoclassical market model. Although visitors did not always reveal their identity when they checked the exhibits, at least the exhibitors were always identifiable through their mapped exhibits. When a potential buyer began a discussion about the exhibited products that could lead to a sales arrangement, both parties exchanged business cards and introduced themselves by describing their industry, products, the market they serve and the country and location of their origin. At this point, as suggested by Callon (2017), the parties involved left the multilateral market arrangement behind and engaged 
in one-on-one negotiations. Usually, this followed an initial inspection of all potentially interesting exhibits by the buyers, during which they eliminated some exhibitors and picked others to be checked out personally in conversations. This selection process depended on aspects such as product designs, materials used, quality of products and price considerations. Therefore, the beginning of bilateral negotiations often followed prior comparisons and calculations without much direct interaction between exhibitors and visitors. We also found that visitors often did not just focus on one potential trade partner but that they split up business with several exhibitors simultaneously (although not with the exactly same designs). Splitting up orders reduced the overall risk of concluding business with firms they did not know before.

However, the Canton Fair was not only about buyers choosing trade partners, but also about exhibitors actively selecting buyers. This was illustrated in one interview when we suggested to the respondent to pause the interview and pay attention to a visitor who had just entered the exhibit. The respondent said that she would prefer to continue our conversation, rather than face the potential buyer. When asked to explain this behavior, she demanded to go off-record and explained that the buyer had tried to cheat on them earlier. Therefore, she would not make business with that buyer again - and not with similar firms she had heard about. She emphasized that "we actively need to select the right buyers". This example illustrates that the interactions between exhibitors and visitors at the Canton Fair were targeted at simplifying the multilateral market context toward one-on-one contract negotiations.

Rather than one specific market mechanism, we identified four types of market configurations at the Canton Fair (Table 2) with different characteristics and spatial consequences in terms of flows of goods, people and knowledge (Table 3).

$* * * * * * * * * * * * * * * * * * * * * * * * * * * * * * * * * * * * *$ 


\section{Type 1: Classic Deal-making}

In this type of market relation, a buyer typically approached an exhibitor, enquired about the products and their characteristics, touched and felt the materials used, and asked about price and delivery conditions. The 'touch and feel' was an important component of checking the exhibits and was part of all four types of market configurations observed (see, also, Borghini et al. 2006). If price negotiations were successful, a contract was signed and a deal concluded on the spot. About one-quarter of all exhibitors in our sample (12 of 51 firms) experienced this form of classic deal-making, especially in the product segments of materials, bulk products and bags (Table 2). A producer from Fujian province operating nine factories in China (established in 1984; 300 employees) described this process as follows: "[We talk about] price, quality, the shipping date, the way of paying. Many customers will directly go to our factory and place the order, and some will directly place the order in the fair. Half and half." It is interesting that most of the firms that engaged in classic deal-making attributed a substantial proportion of their annual sales to the Canton Fair and to contacts made through the event. Half of the firms made at least 60 percent of their entire business through deals initiated at the fair - some almost their entire sales.

However, deals were not just made and then products shipped at a later point. To reduce risk for the producers, advance payments in the range of 20 to 40 percent of the delivery value were demanded - although this number was up for negotiation and generally was much lower if the firms had been business partners before. The representative of an export firm from Jiangsu province (established in 1992; 500 employees) that 'only' generated 10 to 20 percent of its 
annual sales through the Canton Fair described this process as follows: "Even if we sign the contract here we also have some conditions. It is very common that some people sign the contract and then forget it. If they want to get the products, they have to give us some money as a deposit. Normally the deposit is 30 or 40 percent of the entire amount. When the factory produces the products, they will ship them to the port. [There, we] will get a document called 'bill of lading'. We send the document to the buyer, then they will pay the balance to the factory."

This quote also illustrates how flows of products were triggered by the contracts concluded. While the relationship between the parties was not very close, there was certainly enough content to reduce the uncertainty of the transaction. However, more in-depth interactions were not required and further knowledge exchanges usually did not take place. Social interaction was mostly limited to exchanges on the trade fair grounds (see, also, Bathelt and Schuldt 2010). After the event, production details were transmitted by firm representatives to the factory and production began. Overseas delivery via port were subsequently organized and goods transported from the Chinese factory to the overseas port and then on to the buyer's specified site. While these market relations could involve several deliveries over a defined time period, such ongoing deliveries were more likely in the other, more embedded market configurations. We found that classic deal-making relations tended to evolve towards longer-term embedded market relationships (type 2), because repeated transactions between the same partners occurred over consecutive events.

As a consequence, firms observed changes in market interaction. In the early years of the Canton Fair, for instance, American buyers were especially popular among the Chinese exhibitors because they offered generous advance payments (Powell 2007). Others copied these 
patterns and such experiences led to repeated, increasingly more embedded market relations as buyers and sellers began to trust each other and were less concerned about quality issues (compare with Granovetter 1985). A result of these dynamics in the future could be that advance payments become less important when exhibitors get to know their buyers better and more durable transaction relationships develop, as indicated in the prior quote of the Jiangsu firm. From the history of the Canton Fair, we would have expected that the majority of firms were engaged in classic deal-making relations, and not just one-quarter of them.

\section{Type 2: Long-term Stable Customer Relations}

In this type of market relation, exhibitors and visitors knew each other already for an extended time period based on prior transactions; 20 of 51 firms (about 40 percent) engaged in such stable customer relations (Table 2). Often the Chinese exhibitors informed their overseas buyers about their attendance at the Canton fair and invited them to visit their booths. Sometimes, visitors asked the exhibitors to bring certain product designs they wanted to inspect during the event in preparing future contracts. The representative of a small producer from Guangdong province (established in the early 2000s; 100 employees) explained this as follows: "Most [of the visitors at our booth] are old customers. They ask the price, the raw material, or ask us to make some samples. We told them that we will attend the fair so that they come here." The discussions at the fair, however, often did not lead to immediate contractual negotiations and many of the actual sales were not finalized during the event. Discussions during the time of the fair sometimes also went beyond the fair venue and involved social events outside. As a small producer from Jiangsu province (established in 1997; 10-20 employees) suggested: "We know some of [the buyers]. Occasionally, we will talk with them or have dinner together. Generally, 
we learn about the market demand and the change of price." This interaction normally involved more fine-grained knowledge transfers about market changes and customer needs.

However, existing customer relations cannot be taken for granted and there is no guarantee that they will continue. Visitors to the event typically checked out the entire set of participating exhibitors and compared the offerings of their prior partners with those of other firms. As emphasized by Callon (2017), this triggered innovation and differentiation activities on the side of the exhibitors. One small exhibitor from Guangdong province (established in 1988; 20 employees) explained that "[s]ome of our current customers want to see many different producers at one time. So they come to the fair and we must follow their steps. We will arrange meetings and discuss the products and styles with them during the fair." While such scanning of the exhibits of others presented a constant source of uncertainty and a threat to the competitive position of the exhibitors, many were confident that strong social ties from prior interaction supported durable market relationships based on professional trust as described by Ettlinger (2003). The representative of a medium-sized producer from Zhejiang province (established in the early 1990s; 350 employees) emphasized that "[o]ld customers will tell us a lot about the market. For instance, they will tell us that other firms' prices are lower than ours. But they will still do business with us because they trust us. Even though other firms can offer a lower price, our old customers may not trust them. We have a long-term relationship and we are both sure that we can cooperate very well." While the exhibitors were aware that they cannot blindly rely on embedded relationships to be continued, such long-term stable relations entailed knowledge exchanges between buyers and exhibitors that were important in helping exhibiting firms to catch up with market changes and to adapt to new buyer preferences. These knowledge exchanges were also important for exhibitors to gain the attention of new customers. 
In the case of long-term customer relations, contract negotiations usually did not take place during the event - and neither exhibitors nor visitors expected this. Such negotiations were part of regular interactions and meetings between the exhibitors and visitors and were conducted without time pressure in a later bilateral exchange (see, also, Callon 2017). The manager of a Zhejiang firm (established in the early 2000s; 100 employees) described this as follows: "Most of them are old customers or people we already know. If we already know each other or have a good relationship, we will discuss something during the fair. Yes, we will also meet with them. We meet at the factory and have face-to-face talks with them."

In terms of the spatial effects of these market configurations, new production and shipments did not start immediately. However, former contracts were often still in place associated with occasional or regular deliveries of products. Later meetings were arranged, often in the context of annual visits at the producer's plant (Bathelt et al. 2014), to discuss ongoing business relations and negotiate new contracts. Social relations between producers and buyers were much closer than in classic deal-making relations and focused on contents beyond the transaction itself. This led to important knowledge flows about market trends, whereas innovation was typically not an explicit component of such exchanges and the degree of embeddedness of both firms' activities was clearly limited. While still primarily uni-directional, knowledge exchanges increasingly involved bi-directional knowledge flows. Targeted production for the customers occurred in regular or irregular intervals as specified in contractual agreements. The social and spatial linkages between both partners were thus more intense and more frequent than in classic deal-making relations (Table 3). 


\section{Type 3: Immediate Synchronized Customization}

We identified two cases, one shoe firm and one garment firm, with market configurations that we classified as immediate synchronized customization. While we became aware of these distinct cases only after the event, we were able to follow up with one firm's executive by telephone and explore this market configuration further. Although we only observed two cases, we did not find any clues why such relationships should be restricted to these particular firms. In both cases, potential buyers entered the exhibit and began looking around the collection of products, taking some out of the shelves and physically inspecting them in their hands. Once the exhibitor and visitor had introduced themselves and exchanged business cards, negotiations about prices, delivery times and, importantly, about potential modifications took place. This typically left open questions as to whether a specific form of changes could be made to the samples, at what price and how quickly this could be done. Sometimes this was the end to the conversation or another meeting was arranged for the next day.

After the potential buyer left the booth, the exhibitor immediately set up a little display of all models picked and inspected by the previous visitor, added the visitor's business card and a sheet of handwritten notes about the specific interests and requirements of the buyer (Figure 1). The representative then took a digital image of this display and sent it immediately back to the factory. The representative of one export firm from Fujian (established in the early 2000s) explained this process as follows: "Customers choose some of our products; we will note their demand and offer our price to them. If we think they are possible buyers, we will take a photo of all the information and send this to our factory immediately. They will connect with the possible customers soon. If the customers [consider to] buy our product, they might come back to our 
exhibition booth during the fair to confirm some further detail of the product with us. [This] is faster and more effective."

$* * * * * * * * * * * * * * * * * * * * * * * * * * * * * * * * * * * *$

Insert Figure 1 about here

$* * * * * * * * * * * * * * * * * * * * * * * * * * * * * * * * * * * *$

The manager of the firm explained that the firm explicitly instructed the staff at the booth to collect this type of information and transmit it immediately so all details of the customers' wishes and preferences could be collected and stored separately for later market analysis. To wait until after the event meant to mix up a lot of specific knowledge that could help to develop new products and modify future production plans. In addition, this enabled the firm to directly react to the wishes of potential buyers and provide specific responses or quotes. The manager explained the value of the speedy response to potential buyers that could be achieved through this process as follows: "[This way,] we can respond to their requirements very fast. The faster the better, of course. When customers receive your feedback on the same day, or in the early hours [of the next day], they will feel your respect. They will be more likely to do business with you."

The importance of fast responses seemed to be neglected by the majority of exhibitors and was primarily regarded as a post-event process (Rosson and Seringhaus 1995). The fast response to specific questions about design changes or modifications during the fair (rather than in the aftermath) generated an immediate commitment and signaled to the visitors how serious the firm was about a potential market relation. It allowed the exhibitor to signal both flexibility in contractual arrangements and technological and design competencies. The firm's manager explained the immediate synchronized customization process as follows: "When we get the 
information from the trade fair, we will make a customized sample sheet according to their specific requirements and send it to the potential customer by email. But we do not make such sheets for all potential customers. We will first evaluate the possibility of our cooperation, as well as the quality of the firms." This was clearly a targeted and strategic approach adopted by the exhibitor to attract the most promising customers. At the same time, it enabled the firm to systematically collect data about changes in market preferences - data which served as a basis for product modifications and further developments of the product range.

Once responses with suggestions for customization had been send out to a visitor, a new meeting with this visitor was arranged and a later get-together at the factory scheduled for further negotiation and possibly joint redesign or development activities. If no further contact was possible during the event or if further testing and consideration was necessary then contact was re-established and a potential face-to-face meeting scheduled for a later time, possibly leading to a market configuration with follow-up negotiations (type 4).

The impact of this kind of market configuration on social relations and flows of knowledge, people and goods was substantial and led to different outcomes compared to the other market configurations (Table 3). While the firms might not have had prior contacts, the synchronized reaction to the visitors' enquiries signaled immediate commitment and provided evidence of strong manufacturing and design capabilities. The entire approach of the exhibitor was targeted at building sophisticated, embedded customer relationships that enable produceruser learning in the future, as suggested by von Hippel (2001). This type of market relationship led to intensive bi-directional knowledge exchanges and triggered, if successful, the development of trust and ongoing user-led innovation. Future product shipments with changing contents and bi-directional visits of facilities were the likely consequence. 


\section{Type 4: Follow-up Negotiations}

The most common type of market configuration that we observed in almost two-thirds of all cases (32 of 51 firms) was follow-up negotiations (Table 2). Such market relations were not associated with immediate contract negotiations, but involved initial knowledge exchanges during the trade fair that led to further conversations after the event. In former times, exhibitors at the Canton Fair were largely traders with little or no manufacturing experience (Li and Bathelt 2017). The consequence was that these exhibitors did not fully understand the buyers' needs and were not always able to pass on appropriate information to the actual producers or subcontractors. Obviously, this created problems. Also, the prices for products were raised by an additional layer of traders. This structure of market relations changed over time and led to a different type of market configuration as buyers increasingly expected exhibitors to be producers and not just traders.

Former traders were forced to integrate backwards following the expectations of foreign buyers. We found that many exhibitors indeed made this shift. However, some were still traders who exhibited a large selection of designs and product variations, only part of which was produced by them, with the rest coming from partner firms. Because of concerns about price and manufacturing competencies, foreign buyers avoided concluding contracts during the event and established a different set of best-practices that involved follow-up visits and inspections of the factories, before engaging in contract negotiations. Potential buyers came to the exhibits, looked around and inspected the designs, colors and materials of the inventory and used this as a basis to select firms for bilateral negotiations in follow-up meetings (see, also, Rosson and Seringhaus 1995). The manager of a mid-sized firm from Zhejiang province (established in 2009; 400 employees) explained this process as follows: "First, [potential customers] will ask about the 
price - then the quantity of order. Or they will let us make a sample first. They will observe our manufacturing status and technical level throughout the talks. ... We do not expect customers to make deals with us immediately at the trade fair."

The entire interaction process in this market configuration was focused on further meetings and negotiations after the event. The representative of a mid-sized firm from Fujian province (established in 1997; 500 employees) explained that "[w]e do not sign the contract here - zero percent! Some customers from the trade fair will visit our factory, talk about the details and place the order [later on]. It is a longer-term work [process]." This was often successful, as in the case of the Zhejiang firm cited above that concluded few contracts during the event but insisted that about 80 percent of their overall sales were directly due to customer contacts made during the fair.

Not all of the products exhibited by the firms were innovations of their own. Some were samples from former contracts with other customers with those customer's labels removed. We were told that this was a normal process. Nonetheless, many exhibits provided evidence of creativity and a strong design potential. Interestingly - as suggested by Callon (2017) - potential buyers used the information of these innovative exhibits as a primary basis to make their decision about which partners to engage with in bilateral negotiations. However, potential buyers were often not really interested in ordering the products they saw in the exhibits at the fair. Instead, they had their own designs and blueprints, which they wanted to have produced by a Chinese partner. As argued by Loasby (2000), the designs shown were primarily meant to attract buyers - they were not necessarily meant to be sold. As one interviewee from a Zhejiang firm suggested, "[s]ome customers have their own designs, you just need to say you can make similar ones to theirs." However, as opposed to situations in the past, these buyers did not just take all 
what the exhibitors said for granted. They inspected the competencies, cleanliness and quality of the exhibitor's factory before engaging in contract negotiations and signing an order.

In terms of interaction patterns (Table 3), potential buyers selected those partners they thought had the capability to fabricate the pre-specified product designs. They engaged in intensive, sometimes multiple, negotiations after the event at the production site and, if a contract was signed and an order placed, transferred their design and implementation knowledge to the firm. This was followed by several visits and potentially even technicians monitoring the early stages of production runs. While the producer was not asked to innovate at this stage, the transferred knowledge added to the competence base of the firm. Over time, this generated upgrading potential (see Humphry and Schmitz 2002) and some Chinese producers even decided to design their own products for the domestic market. This form of market relation typically involved a range of product designs and included smaller and larger batches that were distributed to the buyer's foreign locations as specified in the contract. Some contracts were even flexible and did not specify in advance a final product range to be produced, but allowed that range to be modified during the process.

\section{Conclusions}

This study explores temporary market geographies and their associated flows of goods, knowledge and people by examining the Canton Fair, a temporary marketplace designed to trigger the export of Chinese products. The paper shows that this event does not generate 'a' single market but rather multiple market configurations that are embedded in different types of relationships between exhibitors and visitors. The event is set up in such a way to enable participants to make a shift from multilateral market relations towards one-on-one negotiation situations and thus exemplifies Callon's (2017) analysis of 'market-agencements'. In our study, 
we were able to identify four types of market configurations at the Canton Fair that were quite common across all industries investigated (Table 2$){ }^{1}$

Specifically, we found that classic deal-making (type 1), where buyers and exhibitors negotiate contracts and conclude deals, still takes place at the event. However, this type of market relationship is less common than expected. A second type of configuration, in which firms interact with existing transaction partners to prepare new, often ongoing, transaction relations, can be classified as long-term stable customer relations (type 2). In a historical perspective, many regular exhibitors started their export activities through the Canton Fair and developed longer-term relations with their clients over repeated transactions, which indicates an evolution of type 1 relations toward type 2. Type 3 market relations of immediate synchronized customization are particularly dynamic, as interactions between exhibitors and potential buyers facilitate quick knowledge exchanges and trust building. Knowledge about customer preferences and requests is transmitted to the factories, followed by customized solutions in an attempt to set up transaction relations in the future. Finally, type 4 market relations are targeted toward generating follow-up negotiations at the factory site that transfer crucial knowledge to the participants.

This sequence of market configurations induces increasingly complex and durable flows of goods, knowledge and people. Since knowledge exchanges become more complex as we move from type 1 to type 4, they involve a shift from short-term communication to ongoing discussions. We explain how these different relations configure changing market geographies with meetings shifting from the fairgrounds to the factory sites of the transaction partners, involving more frequent get-togethers and stimulating closer social relations. In the end, this

${ }^{1}$ Although we cannot claim that these exact types of market relations also dominate other industries, where other market configurations may develop as a consequence of different technology and market contexts, we believe that the general implications of our study do apply more broadly. 
goes along with an evolution from one-off shipments of standardized goods towards ongoing deliveries of products, in line with the customization processes involved (Table 3).

All these configurations deviate from the neoclassical market model that is often viewed as describing 'a' typical market situation. As Callon (1998: 47) concludes in his analysis of market-making processes, "[market regularities] ... remain limited in time and space. It is therefore wrong to talk of laws or, worse still, of the law of the market. There only exist temporary, changing laws associated with specific markets” [emphasis added]. While Callon's (1998) work points at different market situations with different products and different geographical contexts, our evidence extends this view and shows that a variety of substantially different market relationships develop and co-exist at a single event. As indicated in Table 2, many of the firms interviewed are simultaneously involved in several different types of market configurations. The analysis thus clearly supports proposition 1 that multiple types of market relations develop at a single event. As expressed in proposition 3, we also show that the different types of market relationships are associated with different forms of social relations that produce distinct market configurations with varying market geographies (Table 3).

Finally, proposition 2, which suggests that the nature of market relations at trade fairs is intrinsically dynamic, is also confirmed by our research, although supporting evidence is more anecdotal in nature and less systematic. Elsewhere, the functional transformation of the event was traced and the dominance of classic deal-making relations in its early stages documented (Li and Bathelt 2017). Along with the changing nature of the event and China's highly dynamic economic context, diverse market configurations have emerged as identified in this paper that go along with more durable and embedded market and production relations over time. As such, we observe that the Canton Fair is changing from a marketplace for Chinese exporters to a 
diversified social space where relationships are being forged, knowledge is exchanged and trust established.

It is an interesting challenge for future research to examine more systematically how temporary market configurations evolve. When conducting such research, we should keep in mind that the development of market relations at such temporary spatial settings eventually configures different patterns of production and innovation from the perspective of permanent industrial communities and regions. As such, analyses of market relations and producer-user linkages are indeed two sides of the same coin - a finding, which calls for a stronger link of research programs between the fields of industrial marketing and economic geography and for closer future collaboration (e.g. Rinallo et al. 2017).

\section{Acknowledgements}

This paper was presented in 2016 at the Annual Meeting of the Association of American Geographers in San Francisco and the iBEGIN Conference on International Business, Economic Geography, and Innovation in Philadelphia. We would like to thank the audiences of these meetings for helpful comments. In addition, we wish to thank Patrick Cohendet, Francesca Golfetto, Doug Gress, Sebastian Henn and Daniel Hutton Ferris for their suggestions on improving earlier versions of this paper. Financial support was provided through the Canada Research Chair in Innovation and Governance at the University of Toronto.

\section{References}

Aspers, P. and Darr, A. (2011), 'Trade shows and the creation of market and industry', The Sociological Review, 59, 758-778.

Bathelt, H., Golfetto, F. and Rinallo, D. (2014), Trade Shows in the Globalizing Knowledge Economy (Oxford: Oxford University Press).

Bathelt, H. and Schuldt, N. (2010), 'International trade fairs and global buzz, Part I: Ecology of global buzz', European Planning Studies, 18, 1957-1974.

Bathelt, H. and Zeng, G. (2015), 'Trade, knowledge circulation and diverse trade fair ecologies in China', in H. Bathelt and G. Zeng (eds.), Temporary Knowledge Ecologies: The Rise 
of Trade Fairs in the Asia-Pacific Region (Cheltenham, Northampton, MA: Edward Elgar), 154-174.

Berndt, C. and Boeckler, M. (2009), 'Geographies of circulation and exchange: Constructions of markets', Progress in Human Geography, 33, 535-551.

Borghini, S., Golfetto, F. and Rinallo, D. (2006), 'Ongoing search among industrial buyers', Journal of Business Research, 59, 1151-1159.

Callon, M. (1998), 'Introduction: The embeddedness of economic markets in economics', in Callon, M. (ed), The Laws of the Markets (Oxford: Blackwell), 1-57.

Callon, M. (2007), 'What Does It Mean to Say That Economics Is Performative?', in D. MacKenzie, F. Muniesa and L. Siu (eds.), Do Economists Make Markets? On the Performativity of Economics (Princeton, Oxford: Princeton University Press), 311-357.

Callon, M. (2017), 'Revisiting marketization: From interface-markets to market-agencements', in H. Bathelt, P. Cohendet, S. Henn, and L. Simon (eds.), The Edward Elgar Companion to Innovation and Knowledge Creation (Cheltenham, Northampton, MA: Edward Elgar), forthcoming.

China Import and Export Fair (2015), Visitor Guide - The 117th Session of China Import and Export Fair (China Foreign Trade Centre: Guangzhou).

China Import and Export Fair (2016), Canton Fair Online - Statistics (Guangzhou). Online. Available HTTP: <http://www.cantonfair.org.cn/html/cantonfair/en/about/201209/138.shtml> (10 March 2016).

Clark, G. (1998), 'Stylized facts and close dialogue: Methodology in economic geography', Annals of the Association of American Geographers, 88, 73-87.

Dai, G., Zuo, P., Lei, M. and Liang, C. (2012), 'Spatial differentiation of the Canton Fair for exhibitors', Tropical Geography, 32, 30-32 (in Chinese).

Ettlinger, N. (2003), 'Cultural economic geography and a relational and microspace approach to trusts, rationalities, networks, and change in collaborative workplaces', Journal of Economic Geography, 3, 145-172.

Entwistle, J. (2009), The Aesthetic Economy of Fashion: Markets and Value in Clothing and Modelling (Berg: Oxford). 
Evers, N. and Knight, J. (2008), 'Role of international trade shows in small firm internationalization: A network perspective', International Marketing Review, 25, 544562.

Gibson, R. and Bathelt, H. (2014), 'Field configuration or field reproduction? The dynamics of global trade fair cycles', Zeitschrift für Wirtschaftsgeographie, 58, 216-231.

Glückler, J. and Armbrüster, T. (2003), 'Bridging uncertainty in management consulting: The mechanisms of trust and networked reputation', Organization Studies, 24, 269-297.

Glückler, J. and Panitz, R. (2015), How Digital Media Firms Gain Market Intelligence: Temporary Rewiring in Global Supply Networks (Paper presented at the Annual Meeting of the Association of American Geographers in Chicago, IL).

Golfetto, F. (2004), Fiere e Comunicazione: Strumenti per le Imprese e il Territorio (Trade Fairs and Communication: Tools for Firms and the Territory) (Milan: EGEA).

Granovetter, M. (1985), 'Economic action and economic structure: The problem of embeddedness', American Journal of Sociology, 91, 481-510.

Haisch, T. and Menzel, M.-P. (2015), Entanglement und Bewertungen von Objekten am Beispiel von Kunstwerken auf Basler Messen (Entanglement and Valuation of Objects - The Example of Basel Art Fairs) (Paper presented at Tagung Neue Kulturgeographie Meeting New Cultural Geography in Bamberg, Germany)

Humphrey, J. and Schmitz, H. (2002), 'How does insertion in global value chains affect upgrading in industrial clusters?', Regional Studies, 36, 1017-1027.

Jin, X. and Weber, K. (2008), 'The China Import and Export (Canton) Fair: Past, present, and future', Journal of Convention and Event Tourism, 9, 221-34.

Kalafsky, R. V. and Gress, D. R. (2013), 'Trade fairs as an export marketing and research strategy: Results from a study of Korean advanced machinery firms', Geographical Research, 51, 304-317.

Li, P.-F. (2014) 'Global temporary networks of clusters: Structures and dynamics of trade fairs in Asian economies', Journal of Economic Geography, 14, 995-1021.

Li, P. and Bathelt, H. (2017) 'From temporary market to temporary cluster: Evolution of the Canton Fair', Area Development and Policy, doi: 10.1080/23792949.2017.1281085.

Loasby, B. J. (2000), 'Market institutions and economic evolution', Journal of Evolutionary Economics, 10, 297-309. 
Luan, G. (2015), '117th Canton Fair sparkles highlights', International Business Daily - Special Issue on 117th China Import and Export Fair, April 15, B1-B2.

MacKenzie, D. and Millo, Y. (2003), 'Constructing a market, performing theory: The historical sociology of a financial derivatives exchange', American Journal of Sociology, 109, 107145

MacKenzie, D., Muniesa, F. and Siu, L. (2007), 'Introduction', in D. MacKenzie, F. Muniesa and L. Siu (eds.), Do Economists Make Markets? On the Performativity of Economics (Princeton, Oxford: Princeton University Press), 1-19.

Maskell, P., Bathelt, H. and Malmberg, A. (2006), 'Building global knowledge pipelines: The role of temporary clusters', European Planning Studies, 14, 997-1013.

Miles, M. B. and Huberman, A. M. (1994), Qualitative Data Analysis: An Expanded Sourcebook (2nd edn.; Thousand Oaks, CA: Sage).

Moeran, B. and Pedersen, J. S. (2011), 'Introduction', in B. Moeran and J. S. Pedersen (eds.), Negotiating Values in the Creative Industries: Fairs, Festivals and Competitive Events (Cambridge: Cambridge University Press), 1-35.

Norcliffe, G. and Rendace, O. (2003), 'New geographies of comic book production in North America: The new artisans, distancing, and the periodic social economy', Economic Geography, 79, 241-273.

Powell, S. (2007), 'Guangzhou, a microcosm of global trade', Barron's, March 12, 57.

Power, D. and Jansson, J. (2008), 'Cyclical clusters in global circuits: Overlapping spaces in furniture trade fairs', Economic Geography, 84, 423-448.

Ramírez-Pasillas, M. (2008), 'Resituating proximity and knowledge cross-fertilization in clusters by means of international trade fairs', European Planning Studies, 16, 643-663.

Ramírez-Pasillas, M. (2010), 'International trade fairs as amplifiers of permanent and temporary proximities in clusters', Entrepreneurship \& Regional Development, 22, 155-187.

Rinallo, D. and Golfetto, F. (2011), 'Exploring the knowledge strategies of temporary cluster organizers: A longitudinal study of the EU fabric industry trade shows (1986-2006)', Economic Geography, 87, 453-476.

Rinallo, D., Bathelt, H., and Golfetto, F. (2017), 'Economic geography and industrial marketing views on trade shows: Collective marketing and knowledge circulation', Industrial Marketing Management, 61, 93-103. 
Rosson, P. J. and Seringhaus, F. R. (1995), 'Visitor and exhibitor interaction at industrial trade fairs', Journal of Business Research, 32, 81-90.

Seawright, J. and Gerring, J. (2008), 'Case selection techniques in case study research: A menu of qualitative and quantitative options', Political Research Quarterly, 61, 294-308.

Sharland, A. and Balogh, P. (1996), 'The value of nonselling activities at international trade shows', Industrial Marketing Management, 25, 59-66.

Skov, L. (2006), 'The role of trade fairs in the global fashion business', Current Sociology, 54, 764-783.

Thrift, N. (2000), 'Performing cultures in the new economy', Annals of the Association of American Geographers, 90, 674-692.

Tokatli, N. (2015), 'Single-firm case studies in economic geography: Some methodological reflections on the case of Zara', Journal of Economic Geography, 15, 631-647.

von Hippel, E. (2001), 'Innovation by user communities: Learning from open-source software', MIT Sloan Management Review, 42: 82-86.

Yin, R. K. (2009), Case Study Research: Design and Methods (4th edn.; Thousand Oaks, CA: Sage). 
Table 1: Visitors (Buyers) and Revenues at the Canton Fair in Guangzhou, 1957-2015

\begin{tabular}{l|cc|cc}
\hline Year & \multicolumn{2}{|c|}{ Buyers (number) } & \multicolumn{2}{c}{ Business turnover (million USD) } \\
& Spring session & Autumn session & Spring session & Autumn session \\
\hline 1957 & 1,200 & 1,900 & 20 & 70 \\
1960 & 2,700 & 2,500 & 130 & 110 \\
1965 & 5,000 & 6,000 & 330 & 430 \\
1970 & 7,300 & 8,000 & 400 & 510 \\
1975 & 16,700 & 15,900 & 1,250 & 1,400 \\
1980 & 20,600 & 22,000 & 1,900 & 2,500 \\
1985 & 24,600 & 26,900 & 2,550 & 3,100 \\
1990 & 40,400 & 42,200 & 5,650 & 5,700 \\
1995 & 52,400 & 52,600 & 10,800 & 8,600 \\
2000 & 98,000 & 105,000 & 13,650 & 14,950 \\
2005 & 195,500 & 177,000 & 29,250 & 29,450 \\
2010 & 204,000 & 200,600 & 34,300 & n.a. \\
2015 & 184,800 & 177,500 & 28,050 & 27,000 \\
\hline
\end{tabular}

Note: n.a. $=$ not available.

Source: China Import and Export Fair (2016) 
Table 2: Types of Market Configurations between Exhibitors and Visitors of the Canton Fair, 2015

\begin{tabular}{|c|c|c|c|c|c|}
\hline \multicolumn{2}{|l|}{ Category } & $\begin{array}{l}\text { Type 1: } \\
\text { Classic deal- } \\
\text { making }\end{array}$ & $\begin{array}{l}\text { Type 2: } \\
\text { Long-term } \\
\text { stable customer } \\
\text { relations }\end{array}$ & $\begin{array}{l}\text { Type 3: } \\
\text { Immediate } \\
\text { synchronized } \\
\text { customization }^{2)}\end{array}$ & $\begin{array}{l}\text { Type 4: } \\
\text { Follow-up } \\
\text { negotiations }\end{array}$ \\
\hline \multicolumn{2}{|c|}{ Description } & $\begin{array}{l}\text { Sign a } \\
\text { contract and } \\
\text { make a deal } \\
\text { on the spot }\end{array}$ & $\begin{array}{l}\text { Immediate } \\
\text { contractual } \\
\text { arrangements } \\
\text { not necessary; } \\
\text { existing } \\
\text { customer } \\
\text { relations are } \\
\text { strengthened }\end{array}$ & $\begin{array}{l}\text { Initial knowledge } \\
\text { exchange; } \\
\text { customer } \\
\text { preferences } \\
\text { immediately } \\
\text { transmitted to } \\
\text { factory; } \\
\text { synchronized } \\
\text { customization }\end{array}$ & $\begin{array}{l}\text { Initial } \\
\text { knowledge } \\
\text { exchange; } \\
\text { follow-up } \\
\text { contacts after } \\
\text { event to make } \\
\text { appointment } \\
\text { for site visits }\end{array}$ \\
\hline \multirow{4}{*}{$\begin{array}{l}\text { Firm } \\
\text { interview } \\
\text { ID by } \\
\text { industry } \\
\text { group }\end{array}$} & $\begin{array}{l}\text { Textiles and } \\
\text { garments }\end{array}$ & 109,319 & $\begin{array}{l}109,111,112, \\
115,211,314, \\
316\end{array}$ & 319 & $\begin{array}{l}109-113,115- \\
116,214-216, \\
312,313,315, \\
317-319\end{array}$ \\
\hline & Shoes & $\begin{array}{l}104,107, \\
206\end{array}$ & $\begin{array}{l}106,208,209, \\
309\end{array}$ & 307 & $\begin{array}{l}104,105,106, \\
107,209,306, \\
308\end{array}$ \\
\hline & $\begin{array}{l}\text { Bags and } \\
\text { cases }\end{array}$ & $\begin{array}{l}101,201, \\
202,301- \\
304\end{array}$ & $\begin{array}{l}101,201-203, \\
210,302,304, \\
310,311\end{array}$ & & $\begin{array}{l}102,108,203, \\
204,302,310, \\
311\end{array}$ \\
\hline & Others & & & & 217,305 \\
\hline \multicolumn{2}{|c|}{$\begin{array}{l}\text { Total number of firms } \\
(\mathrm{n}=51)^{1)}\end{array}$} & 12 & 20 & 2 & 32 \\
\hline \multicolumn{2}{|c|}{ Share of total (\%) } & 24 & 39 & 4 & 63 \\
\hline
\end{tabular}

Notes: ${ }^{1)}$ Of the 55 firms interviewed, 51 could be accurately assigned to a specific market configuration; numerous of these firms were assigned to more than one type. ${ }^{2)}$ Type 3 was discovered by accident and reconstructed ex-post. This market relation may be more frequent than indicated in the table. 
Table 3: Interaction Patterns and Spatial Consequences in Exhibitor-Visitor Interaction at the Canton Fair by Type of Market Configuration, 2015

\begin{tabular}{|c|c|c|c|c|}
\hline Category & $\begin{array}{l}\text { Type 1: } \\
\text { Classic deal- } \\
\text { making }\end{array}$ & $\begin{array}{l}\text { Type } 2 \text { : } \\
\text { Long-term stable } \\
\text { customer relations }\end{array}$ & $\begin{array}{l}\text { Type } 3 \text { : } \\
\text { Immediate synchronized } \\
\text { customization }\end{array}$ & $\begin{array}{l}\text { Type 4: } \\
\text { Follow-up } \\
\text { negotiations }\end{array}$ \\
\hline $\begin{array}{l}\text { Durability } \\
\text { of } \\
\text { interaction }\end{array}$ & $\begin{array}{l}\text { Interaction only } \\
\text { during event; } \\
\text { but this may } \\
\text { change in } \\
\text { future }\end{array}$ & $\begin{array}{l}\text { Repeated } \\
\text { interaction at } \\
\text { event and at } \\
\text { factory }\end{array}$ & $\begin{array}{l}\text { Initial short-term } \\
\text { interaction with potential } \\
\text { to become embedded in } \\
\text { the longer-term }\end{array}$ & $\begin{array}{l}\text { Repeated } \\
\text { interaction at event } \\
\text { and decision- } \\
\text { making at factory }\end{array}$ \\
\hline $\begin{array}{l}\text { Intensity of } \\
\text { interaction }\end{array}$ & $\begin{array}{l}\text { No close } \\
\text { contact; simple } \\
\text { knowledge } \\
\text { exchanges }\end{array}$ & $\begin{array}{l}\text { Ongoing } \\
\text { customer relations } \\
\text { with knowledge } \\
\text { exchanges based } \\
\text { on experience and } \\
\text { professional trust }\end{array}$ & $\begin{array}{l}\text { No close initial contact; } \\
\text { but immediate } \\
\text { customization and } \\
\text { responsiveness to quickly } \\
\text { build embedded relations } \\
\text { and initial trust }\end{array}$ & $\begin{array}{l}\text { Close customer } \\
\text { relations with } \\
\text { bilateral } \\
\text { knowledge } \\
\text { exchanges based } \\
\text { on embedded trust- } \\
\text { based relations }\end{array}$ \\
\hline $\begin{array}{l}\text { Induced } \\
\text { knowledge } \\
\text { flows }\end{array}$ & $\begin{array}{l}\text { Simple uni- } \\
\text { directional } \\
\text { knowledge } \\
\text { about product } \\
\text { and delivery } \\
\text { features }\end{array}$ & $\begin{array}{l}\text { Intensive uni- } \\
\text { directional } \\
\text { knowledge about } \\
\text { contractual } \\
\text { matters and } \\
\text { market changes; } \\
\text { beginning bi- } \\
\text { directional flows }\end{array}$ & $\begin{array}{l}\text { Intensive bi-directional } \\
\text { knowledge about product } \\
\text { variation, customer } \\
\text { preferences, market } \\
\text { development and } \\
\text { innovation potential }\end{array}$ & $\begin{array}{l}\text { Intensive bi- } \\
\text { directional } \\
\text { knowledge } \\
\text { exchanges and uni- } \\
\text { directional } \\
\text { knowledge } \\
\text { transfers }\end{array}$ \\
\hline $\begin{array}{l}\text { Induced } \\
\text { travel of } \\
\text { people }\end{array}$ & None & $\begin{array}{l}\text { Regular (annual) } \\
\text { meetings at } \\
\text { factory }\end{array}$ & $\begin{array}{l}\text { None immediately; but } \\
\text { potential mobility with } \\
\text { longer-term commitment } \\
\text { in future }\end{array}$ & $\begin{array}{l}\text { Regular meetings } \\
\text { at factory to } \\
\text { implement new } \\
\text { production }\end{array}$ \\
\hline $\begin{array}{l}\text { Induced } \\
\text { flows of } \\
\text { goods }\end{array}$ & $\begin{array}{l}\text { Delivery from } \\
\text { producer soon } \\
\text { after event }\end{array}$ & $\begin{array}{l}\text { Regular or } \\
\text { irregular } \\
\text { deliveries from } \\
\text { producer } \\
\text { according to } \\
\text { contract }\end{array}$ & $\begin{array}{l}\text { Joint innovation may lead } \\
\text { to ongoing changes of } \\
\text { products and frequent } \\
\text { delivery updates }\end{array}$ & $\begin{array}{l}\text { Regular deliveries } \\
\text { from producer } \\
\text { according to } \\
\text { contract }\end{array}$ \\
\hline
\end{tabular}


Figure 1: Illustration of the Immediate Synchronized Customization Process (Type 3 Market Configuration) at the Canton Fair, 2015

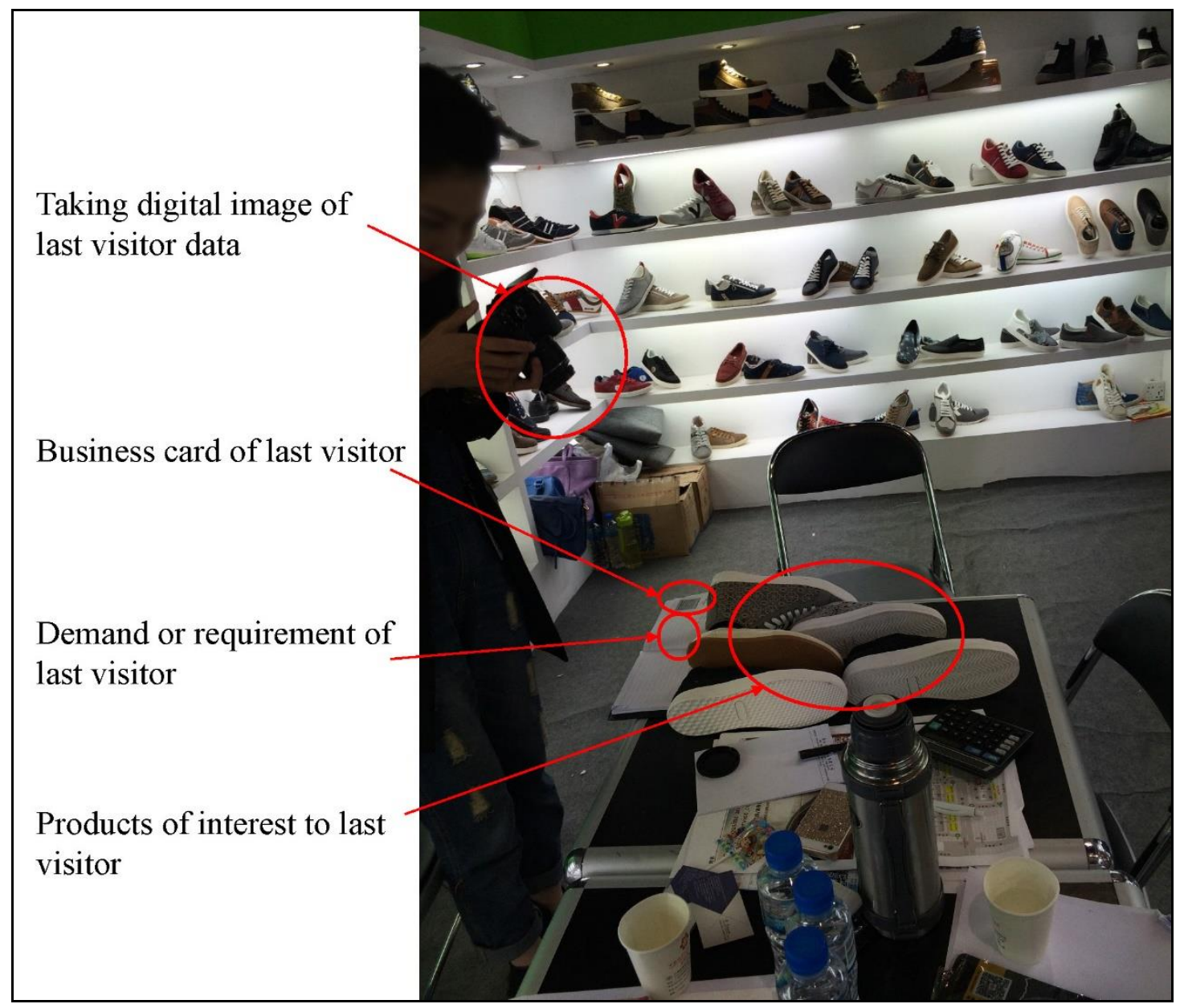

